$\begin{array}{llllllllllll}\text { A C T A C H E I C A } & \text { S C A N D I N A V I C A } & 24 & (1970) & 50-54\end{array}$

\title{
Chlorination of Benzyl Esters of Aliphatic Acids
}

\author{
ERK K I K. E URA N TO and LASSE M. HA UTO N IEM I
}

Department of Chemistry, University of Turku, Turku 2, Finland

\begin{abstract}
$\alpha$-Chlorobenzyl esters of acetic, formic, trichloroacetic, and trifluoroacetic acids have been prepared by chlorinating the corresponding benzyl esters in ultraviolet light at $0^{\circ} \mathrm{C}$. The first-mentioned ester decomposed to benzaldehyde and acetyl chloride during distillation, already at temperatures below $30^{\circ} \mathrm{C}$. Continued chlorination of benzyl trifluoroacetate led to the formation of hexachlorocyclohexylchloromethyl trifluoroacetate, which was hydrolysed to hexachlorocyclohexanecarbaldehyde, which in turn was reduced to hexachlorocyclohexylmethanol.
\end{abstract}

$\alpha$-Haloalkyl esters of both aliphatic and aromatic acids (for a survey of available synthetic methods, see Euranto et al. ${ }^{1}$ ) as well as $\alpha$-halobenzyl esters of aromatic acids ${ }^{2}$ are well known. On the other hand, only a few $\alpha$-halobenzyl and related esters of aliphatic acids have been described. Of the possible methods of preparation, ${ }^{1}$ those based on reactions between aromatic aldehydes and aliphatic acyl halides usually lead to tarry products ${ }^{3}$ from which the esters cannot be isolated. Only the reactions of oxalyl halides with aromatic aldehydes have been found to yield isolable esters (bis( $\alpha$-chlorocinnamyl) oxalate, ${ }^{4}$ bis $\left(\alpha\right.$-chlorobenzyl) oxalate, ${ }^{5}$ bis-( $\alpha$-bromobenzyl) oxalate, ${ }^{5}$ and several substituted $\alpha$-chloro- and $\alpha$-bromobenzyl oxalates $\left.{ }^{6}\right)$. Other known $\alpha$-halobenzyl esters of aliphatic acids include $\alpha$-chlorobenzyl chloroformate, bis $(\alpha$-chlorobenzyl) carbonate, and $\alpha$-chlorobenzyl $\alpha, \beta, \beta, \beta$-tetrachloroethyl carbonate prepared from phosgene and aldehydes in the presence of tertiary organic bases. ${ }^{7}$ In this paper are described the results of experiments in which $\alpha$-chlorobenzyl esters of aliphatic acids were prepared by chlorination of benzyl esters.

\section{EXPERIMENTAL}

Method of chlorination and analysis of products. Benzyl esters were chlorinated with gaseous chlorine at $0^{\circ} \mathrm{C}$ in ultraviolet light in a Hanovia Photochemical Reactor. The progress of the reactions was followed by analysing samples taken from the reaction mixtures by gas chromatography. The $\alpha$-chlorobenzyl esters decomposed at the tempera. tures employed (e.g., $120^{\circ} \mathrm{C}$ at the injection block) in gas chromatography to acyl chloride and benzaldehyde. Benzoyl chloride was usually one of the reaction products; it was probably formed from benzaldehyde by chlorination. ${ }^{8}$ After the desired degree of chlorina- 
tion, excess chlorine, hydrogen chloride, acyl chlorides, and other volatile products were removed in a vacuum. The $\alpha$-chlorobenzyl ester was then isolated from other reaction products by distillation in a vacuum, often at room temperature to avoid decomposition.

The presence of an $\alpha$-chlorobenzyl ester in a reaction mixture or distillate fraction containing also other hydrolysable compounds was determined kinetically by measuring the rate of hydrolysis in an appropriate acetone-water mixture conductometrically and comparing it with an estimated value. Also the relative amounts of hydrolysable products could be determined approximately in this way. The final products were analysed by hydrolysing weighed amounts in water and titrating with standard sodium hydroxide and silver nitrate solutions. Sometimes also the total chlorine content was determined by the method of Carius. The results are given in the following as percentages of the theoretical amounts calculated by taking into account that the hydrolysis products of an $\alpha$-chlorobenzyl ester are a carboxylic acid, hydrogen chloride, and benzaldehyde.

The infrared spectra were recorded with a Perkin-Elmer Model 337 Grating Infrared Spectrophotometer without solvent. The proton magnetic resonance spectra of the hexachlorocyclohexyl compounds were recorded on either a $60 \mathrm{Mcs}$ Varian Model A-60A (in the University of Helsinki) or a 100 Mes Perkin-Elmer Model R12 NMR spectrometer (in Perkin-Elmer Laboratories, Beaconsfield) and those of other esters on a 60 Mcs Perkin-Elmer Model R10 NMR spectrometer (in this laboratory) using TMS as internal standard.

Starting materials. Benzyl acetate was a commercial product (BDH). Benzyl formate was a product prepared earlier in this laboratory by Dr. H. Laato. ${ }^{9}$ The other benzyl esters were prepared from benzyl alcohol (BDH) and the acids using $p$-toluenesulfonic acid as catalyst and removing water by azeotropic distillation with methylene chloride. Physical constants of the prepared benzyl esters are: benzyl chloroacetate (prepared for comparison), b.p. $79-81^{\circ} \mathrm{C} / 1$ torr (lit. ${ }^{10} 147.5^{\circ} \mathrm{C} / 9$ torr), $n_{\mathrm{D}}{ }^{20} 1.5243$ (lit. ${ }^{10} n_{\mathrm{D}}{ }^{18} 1.5246$ ); benzyl trichloroacetate, b.p. $73-78^{\circ} \mathrm{C} / 1$ torr (lit. ${ }^{10} 178.5^{\circ} \mathrm{C} / 50$ torr), purity (by gas chromatography) $95-97 \%, n_{\mathrm{D}}{ }^{20} 1.5289$ (lit. ${ }^{10} n_{\mathrm{D}}{ }^{18.8} 1.5288$ ), $d_{4}{ }^{20} 1.3796$ (lit. ${ }^{10} d_{4}{ }^{4} 1.3887$ ), $[R]_{\mathrm{D}} 56.66$ (calc. ${ }^{11} 56.88$ ); benzyl trifluoroacetate, b.p. $70-71^{\circ} \mathrm{C} / 10$ torr (lit. $177-178^{\circ} \mathrm{C} / 755$ torr, ${ }^{12} 50-52^{\circ} \mathrm{C} / 5$ torr $\left.{ }^{13}\right), n_{\mathrm{D}}{ }^{20} 1.4377$ (lit. ${ }^{12} n_{\mathrm{D}}{ }^{18} 1.4363$ ), $d_{4}{ }^{20} 1.2446$ (lit. ${ }^{13} d_{22^{22}}{ }^{22} 1.2419$ ), $[R]_{\mathrm{D}} 43.03$ (calc. ${ }^{11} 41.23$, if $[R]_{\mathrm{D}}$ for $\mathrm{F}$ is 0.81 ). Infrared spectra for the benzyl trihaloacetates are: benzyl trichloroacetate, $v_{\max } 3090 \mathrm{w}, 3070 \mathrm{w}, 3040 \mathrm{w}, 2960 \mathrm{w}, 1770 \mathrm{~s}(\mathrm{C}=\mathrm{O})$, $1500 \mathrm{w}, 1460 \mathrm{~m}, 1380 \mathrm{w}, 1220 \mathrm{~s}, 1000 \mathrm{~m}, 960 \mathrm{~m}, 890 \mathrm{w}, 830 \mathrm{~s}, 755 \mathrm{~m}, 735 \mathrm{w}, 697 \mathrm{~m}, 680 \mathrm{~s} \mathrm{~cm}^{-1}$; benzyl trifluoroacetate, $v_{\max } 3100 \mathrm{w}, 3070 \mathrm{w}, 3040 \mathrm{w}, 2970 \mathrm{w}, 1790 \mathrm{~s}(\mathrm{C}=\mathrm{O}), 1500 \mathrm{w}, 1460 \mathrm{~m}$, $1420 \mathrm{~m}, 1350 \mathrm{~m}, 1225 \mathrm{~s}, 1150 \mathrm{~s}, 1080 \mathrm{w}, 1030 \mathrm{w}, 940 \mathrm{w}, 910 \mathrm{w}, 830 \mathrm{w}, 778 \mathrm{~m}, 752 \mathrm{~m}, 730 \mathrm{~m}$, $698 \mathrm{~m}, 610 \mathrm{w} \mathrm{cm}^{-1}$ ( $\mathrm{s}=$ strong, $\mathrm{m}=$ medium, $\mathrm{w}=$ weak).

$\alpha$-Chlorobenzyl formate. The chlorination of benzyl formate yielded mainly, benzyl chloroformate and $\alpha$-chlorobenzyl formate which were separated from each other and their decomposition products (benzyl chloride ${ }^{14}$ and benzaldehyde, respectively) by fractional distillation. $\alpha$-Chlorobenzyl formate was found to have the highest boiling point of these compounds; the last distillate fractions were relatively pure $\alpha$-chlorobenzyl formate. Physical constants: b.p. $45-50^{\circ} \mathrm{C} / 0.2-0.5$ torr, $n_{\mathrm{D}}{ }^{20} 1.5287, d_{4}{ }^{20} 1.2276,[R]_{\mathrm{D}}$ 42.84 (calc. ${ }^{11} 42.05$ ). Analysis: acids $95.6 \%$, chlorine $97.3 \%$ of theory. Infrared spectrum: $v_{\max } 3470 \mathrm{w}, 3070 \mathrm{~m}, 3040 \mathrm{~m}, 2950 \mathrm{~m}, 2230 \mathrm{w}, 2080 \mathrm{w}, 1960 \mathrm{w}, 1890 \mathrm{w}, 1740 \mathrm{~s}(\mathrm{C}=\mathrm{O}), 1600 \mathrm{w}$, $1495 \mathrm{~m}, 1460 \mathrm{~m}, 1355 \mathrm{~m}, 1315 \mathrm{w}, 1295 \mathrm{w}, 1250 \mathrm{~m}, 1120 \mathrm{~s}, 1030 \mathrm{w}, 1005 \mathrm{w}, 960 \mathrm{~m}, 920 \mathrm{w}, 890 \mathrm{~m}$, $785 \mathrm{w}, 760 \mathrm{~m}, 705 \mathrm{~s}, 620 \mathrm{w}, 600 \mathrm{~m} \mathrm{~cm}^{-1}$.

$\alpha$-Chlorobenzyl acetate. Preliminary experiments indicated that distillation of the chlorination products of benzyl acetate gave even at $23-38^{\circ} \mathrm{C} / 0.1$ torr mainly benzaldehyde, benzoyl chloride, and benzyl chloroacetate, but not $\alpha$-chlorobenzyl acetate. A fraction boiling at $25-32^{\circ} \mathrm{C} / 0.05$ torr was found to contain $\alpha$-chlorobenzyl acetate and other products, but the isolation of pure $\alpha$-chlorobenzyl acetate was found to be impossible by the employed methods. The purest fraction obtained was the distillation residue from which the more volatile compounds had been evaporated at room temperature and $0.05-0.1$ torr. Infrared spectrum: $v_{\max } 3510 \mathrm{w}, 3070 \mathrm{~m}, 3040 \mathrm{~m}, 2990 \mathrm{w}, 1960 \mathrm{w}$, $1770 \mathrm{~s}(\mathrm{C}=\mathrm{O}), 1600 \mathrm{w}, 1500 \mathrm{~m}, 1460 \mathrm{~m}, 1430 \mathrm{w}, 1375 \mathrm{~m}, 1245 \mathrm{~m}, 1200 \mathrm{~s}, 1100 \mathrm{w}, 1080 \mathrm{~m}, 1640 \mathrm{~s}$, $1025 \mathrm{~m}, 990 \mathrm{~m}, 960 \mathrm{w}, 910 \mathrm{~m}, 875 \mathrm{~m}, 835 \mathrm{~m}, 780 \mathrm{w}, 705 \mathrm{~s}, 600 \mathrm{~m} \mathrm{~cm}^{-1}$.

$\alpha$-Chlorobenzyl trichloroacetate. The chlorination product of benzyl trichloroacetate was fractionated twice at reduced pressure. The fraction that contained the least impurities was then held at a pressure of about 0.01 torr at room temperature to remove volatile decomposition products. Physical constants: b.p. $80^{\circ} \mathrm{C} / 0.1-0.2$ torr, $n_{\mathrm{D}}{ }^{20} 1.5360, d_{4}{ }^{20}$

Acta Chem. Scand. 24 (1970) No. 1 
$1.4682,[R]_{\mathrm{D}} 61.16$ (calc. ${ }^{11} 61.69$ ). Analysis: acids $105.2 \%$, chlorine (hydrolysable) $104.2 \%$ of theory. Infrared spectrum: $v_{\max } 3550 \mathrm{w}, 3070 \mathrm{~m}, 3040 \mathrm{~m}, 3000 \mathrm{w}, 2170 \mathrm{w}, 1960 \mathrm{w}, 1890 \mathrm{w}$, $1785 \mathrm{~s}(\mathrm{C}=\mathrm{O}), 1590 \mathrm{w}, 1500 \mathrm{~m}, 1450 \mathrm{~m}, 1355 \mathrm{~m}, 1335 \mathrm{~m}, 1315 \mathrm{~m}, 1250 \mathrm{~m}, 1215 \mathrm{~s}, 1195 \mathrm{~m}$, $1105 \mathrm{w}, 1080 \mathrm{w}, 1030 \mathrm{w}, 1000 \mathrm{~s}, 950 \mathrm{~m}, 920 \mathrm{w}, 845 \mathrm{~s}, 825 \mathrm{~s}, 790 \mathrm{w}, 750 \mathrm{~m}, 710 \mathrm{~s}, 695 \mathrm{w}, 680 \mathrm{w}$, $605 \mathrm{w} \mathrm{cm}{ }^{-1}$. NMR spectrum $\left(\mathrm{CCl}_{4}\right): \tau 2.3-2.8 \mathrm{ppm}$ (both aliphatic and aromatic protons; complex).

$\alpha$-Chlorobenzyl trifluoroacetate. The chlorination product of benzyl trifluoroacetate was distilled twice at reduced pressure. The purest fraction contained $0.5-1 \%$ impurities with lower and $2-3 \%$ with higher boiling points (as determined by gas chromatography). Physical constants: b.p. $38-40^{\circ} \mathrm{C} / 2$ torr, $n_{\mathrm{D}}{ }^{20} 1.4538, d_{\mathrm{A}^{20}} 1.3461$, $[R]_{\mathrm{D}} 47.98$ (calc.11 46.04, if $[R]_{\mathrm{D}}$ for $\mathrm{F}$ is 0.81 ). Analysis: acids $102 \%$, chlorine $102 \%$ of theory. Infrared spectrum: $v_{\max } 3610 \mathrm{w}, 3075 \mathrm{~m}, 3040 \mathrm{~m}, 1960 \mathrm{w}, 1890 \mathrm{w}, 1805 \mathrm{~s}(\mathrm{C}=\mathrm{O}), 1600 \mathrm{w}, 1540 \mathrm{w}, 1500 \mathrm{~m}, 1460 \mathrm{~m}$, $1375 \mathrm{~m}, 1340 \mathrm{~m}, 1330 \mathrm{w}, 1310 \mathrm{~m}, 1230 \mathrm{~s}, 1180 \mathrm{~s}, 1130 \mathrm{~s}, 1080 \mathrm{w}, 1030 \mathrm{w}, 1005 \mathrm{w}, 955 \mathrm{~m}, 910 \mathrm{~m}$, $880 \mathrm{w}, 825 \mathrm{~m}, 790 \mathrm{w}, 770 \mathrm{~m}, 740 \mathrm{w}, 710 \mathrm{~m}, 698 \mathrm{~m}, 615 \mathrm{w}, 595 \mathrm{w} \mathrm{cm}{ }^{-1}$. NMR spectrum $\left(\mathrm{CCl}_{4}\right):$ $\tau 2.3-2.8 \mathrm{ppm}$ (both aliphatic and aromatic protons, complex).

Hexachlorocyclohexylchloromethyl trifluoroacetate. Because the chlorination of benzyl trifluoroacetate yielded in addition to $\alpha$-chlorobenzyl trifluoroacetate also high-boiling viscous products, a more intensive chlorinstion was performed in ultraviolet light at $0^{\circ} \mathrm{C}$ to clarify their composition. It was found that three moles of chlorine added to the phenyl group of $\alpha$-chlorobenzyl trifluoroacetate; the compound was thus hexachlorocyclohexylchloromethyl trifluoroacetate (no $\alpha, \alpha$-dichlorobenzyl ester could be detected). Physical constants: b.p. $107-108^{\circ} \mathrm{C} / 0.01-0.05$ torr, $n_{\mathrm{D}}{ }^{20} 1.5067, d^{20} 1.7335,[R]_{\mathrm{D}} 77.44$ (calc. ${ }^{11} 76.28$, if $[R]_{\mathrm{D}}$ for $\mathrm{F}$ is 0.81 ). Analysis: acids $98.2 \%$, chlorine (hydrolysable) $94.9 \%$, chlorine (total, by the Carius method) $96.4 \%$ of theory. Infrared spectrum: $v_{\max } 3010 \mathrm{~m}$, $2990 \mathrm{~m}, 1820 \mathrm{~s}(\mathrm{C}=\mathrm{O}), 1460 \mathrm{w}, 1400 \mathrm{w}, 1370 \mathrm{w}, 1340 \mathrm{~m}, 1230 \mathrm{~s}, 1180 \mathrm{~s}, 1120 \mathrm{~s}, 1040 \mathrm{w}, 1005 \mathrm{~m}$, $945 \mathrm{w}, 930 \mathrm{w}, 900 \mathrm{~m}, 880 \mathrm{w}, 835 \mathrm{w}, 803 \mathrm{w}, 785 \mathrm{w}, 770 \mathrm{~m}, 740 \mathrm{w}, 720 \mathrm{~m}, 695 \mathrm{w} \mathrm{cm} \mathrm{cm}^{-1}$. NMR spectrum $\left(\mathrm{CCl}_{4}\right): \quad \tau \quad 2.6-3.3 \quad\left(\mathrm{C}_{6} \mathrm{H}_{5} \mathrm{Cl}_{6} \mathrm{CHClO}-\right.$, complex), 4.7 (singlet from $\mathrm{C}_{6} \mathrm{H}_{5} \mathrm{Cl}_{6} \mathrm{CH}_{2} \mathrm{OCOCF}_{3}$ ? $), 4.8-6.0 \mathrm{ppm}\left(\mathrm{C}_{6} \mathrm{H}_{5} \mathrm{Cl}_{6} \mathrm{C}\right.$-, complex $)$.

Hexachlorocyclohexanecarbaldehyde. $12 \mathrm{~g}$ of hexachlorocyclohexylchloromethyl trifluoroacetate was hydrolysed completely by the calculated amount of water dissolved in acetone. Acetone was evaporated under vacuum and the aldehyde was extracted with methylene chloride after neutralization of the residue, dried with anhydrous calcium chloride, and distilled; b.p. $145-147^{\circ} \mathrm{C} / 0.7-0.8$ torr, yield $4 \mathrm{~g}$. The product was a highly viscous, colourless liquid with a characteristic odour. Infrared spectrum: $\nu_{\max } 3470 \mathrm{w}$, $2980 \mathrm{~m}, 2960 \mathrm{w}, 2860 \mathrm{~m}$ (CHO), 2740w, 2500w, 1800m, 1750s (C=O), 1460w, 1380w, 1340m, $1315 \mathrm{w}, 1270 \mathrm{w}, 1225 \mathrm{~m}, 1175 \mathrm{w}, 1135 \mathrm{~m}, 1070 \mathrm{w}, 1040 \mathrm{w}, 998 \mathrm{w}, 958 \mathrm{~m}, 887 \mathrm{~m}, 830 \mathrm{w}, 790 \mathrm{~m}$, $769 \mathrm{~m}, 740 \mathrm{w}, 699 \mathrm{~m}, 620 \mathrm{w} \mathrm{cm}^{-1}$. NMR spectrum $\left(\mathrm{CCl}_{4}\right): \tau 0.4-0.9$ (-CHO, several peaks), 4.7-6.0 ppm $\left(\mathrm{C}_{6} \mathrm{H}_{5} \mathrm{Cl}_{6}-\right.$, complex). The aldehyde gave with dinitrophenylhydrazine a yellow hydrazone.

Hexachlorocyclohexylmethanol. $7.6 \mathrm{~g}$ of hexachlorocyclohexanecarbaldehyde was treated with $1.5 \mathrm{~g}$ of lithium aluminium hydride in ethereal solution at $0^{\circ} \mathrm{C}$. After hydrolysis, the ether layer was dried with anhydrous magnesium sulfate and distilled. About $3 \mathrm{~g}$ of a thick, slightly greenish liquid with a boiling point of $140^{\circ} \mathrm{C} / 0.1$ torr was obtained. The liquid dissolved easily in tetrachloromethane; a white crystalline compound separated from the solution after some time. The infrared and NMR spectra of the original thick liquid and the crystalline compound were of the same type but differed in details. The following data are for the crystalline compound. Analysis: chlorine (total, by the Carius method) $95 \%$ of theory. Infrared spectrum: $v_{\max } 3320 \mathrm{~s}$ (broad, $-\mathrm{OH}$ ), $2980 \mathrm{~m}, 2960 \mathrm{~m}$, $2890 \mathrm{w}, 1630 \mathrm{w}, 1460 \mathrm{~m}, 1405 \mathrm{w}, 1370 \mathrm{w}, 1340 \mathrm{w}, 1320 \mathrm{w}, 1260 \mathrm{w}, 1240 \mathrm{w}, 1230 \mathrm{w}, 1215 \mathrm{~m}$, $1140 \mathrm{w}, 1120 \mathrm{w}, 1090 \mathrm{~m}, 1080 \mathrm{~m}, 1030 \mathrm{w}, 1005 \mathrm{w}, 970 \mathrm{w}, 905 \mathrm{w}, 888 \mathrm{~m}, 827 \mathrm{w}, 782 \mathrm{~m}, 760 \mathrm{~m}$, $706 \mathrm{~m}, 650 \mathrm{~m}, 620 \mathrm{~m}, 563 \mathrm{~m}, 500 \mathrm{w}, 490 \mathrm{~m}, 430 \mathrm{~m} \mathrm{~cm}{ }^{-1}$. NMR spectrum $\left(100 \mathrm{Mcs},\left(\mathrm{CD}_{3}\right)_{2} \mathrm{SO}\right):$ $\tau$ 4.8-5.15 $\left(\mathrm{C}_{6} \mathrm{H}_{5} \mathrm{Cl}_{6} \mathrm{C}\right.$-, equatorial protons?, multiplet $), 5.4-5.6\left(\mathrm{C}_{6} \mathrm{H}_{5} \mathrm{Cl}_{6} \mathrm{C}\right.$-, axial protons?, multiplet), 5.9-6.2 (- $\mathrm{CH}_{2}-$, quadruplet with $\left.J_{\text {gem }} 12 \mathrm{cps}\right), 6.55 \mathrm{ppm}$ (broad singlet, $-\mathrm{OH}$ and $\mathrm{H}_{2} \mathrm{O}$ ). 


\section{CONCLUSIONS}

The results of the experiments in which benzyl esters were chlorinated in ultraviolet light at $0^{\circ} \mathrm{C}$ show that $\alpha$-chlorobenzyl esters can be prepared by this method. Its use is evidently limited to compounds which do not have too many hydrogen atoms in the acyl part and especially by the thermal lability of $\alpha$-chlorobenzyl esters. Seelig ${ }^{15}$ chlorinated benzyl acetate in 1889 . No chlorination was found to take place at room temperature; the probable reason was the lack of a sufficiently intense source of light. At higher temperatures the main reaction products were found to be acetyl and benzoyl chlorides. Seelig assumed that $\alpha$-chlorobenzyl acetate was the primary reaction product which immediately decomposed to acetyl chloride and benzaldehyde, which was then chlorinated. The present results confirm this assumption because $\alpha$-chlorobenzyl acetate was found to be the principal chlorination product at $0^{\circ} \mathrm{C}$. It did not withstand distillation even at $25-30^{\circ} \mathrm{C}$ and decomposed on standing at room temperature for a few days. The $\alpha$-chlorobenzyl esters of formic and, especially, trichloroacetic and trifluoroacetic acids were found to be much more stable; the last two esters had not decomposed substantially during one year when stored in stoppered vessels in a refrigerator. This is in accord with the earlier observation ${ }^{16}$ that the stabilities of $\alpha$-chloro-sec.-alkyl esters are much higher when there are additional chlorine atoms in the molecule.*

Continued chlorination in ultraviolet light was found to lead to the formation of hexachlorocyclohexylchloromethyl esters, which can be hydrolysed to hexachlorocyclohexanecarbaldehyde reducible to hexachlorocyclohexylmethanol. To our knowledge, these compounds have not been described before. They may exist in several isomeric forms. Their infrared and NMR spectra as well as the fact that they were first isolated as highly viscous liquids indicate that they were mixtures of several isomers or conformers. The last-mentioned compound probably crystallised from carbon tetrachloride as a nearly pure isomer.

It is well known that the different carbonyl compounds have characteristic carbonyl stretching frequencies. It is therefore interesting to compare the frequencies for $\alpha$-chlorobenzyl esters with those for some related compounds (Table 1). The frequency is seen to depend on the structure of the acyl component of $\alpha$-chlorobenzyl esters similarly as in the case of other esters including benzyl esters. The frequencies for $\alpha$-chlorobenzyl esters are somewhat higher than those for corresponding chloromethyl ${ }^{17}$ and $\alpha$-chloroethyl esters. Hexachlorocyclohexylchloromethyl trifluoroacetate has a still higher carbonyl stretching frequency in accord with the high electronegativity of the hexachlorocyclohexyl group.

* Note added in proof. I. Horman, S. S. Friedrich, R. M. Keefer, and L. J. Andrews have recently (J. Org. Chem. 34 (1969) 905) found that $\alpha$-bromobenzyl acetate is formed when benzyl acetate is treated with $N$-bromosuccinimide in the presence of benzoyl peroxide in carbon tetrachloride solution at $77^{\circ} \mathrm{C}$. They concluded from their data that under the reaction conditions used the production of benzaldehyde directly from the radical $\mathrm{C}_{6} \mathrm{H}_{5} \dot{\mathrm{C}} \mathrm{HOCOCH} \mathrm{H}_{3}$ is of importance in addition to its formation from $\alpha$-bromobenzyl acetate.

Acta Chem. Scand. 24 (1970) No. 1 
Table 1. The carbonyl stretching frequencies (in $\mathrm{cm}^{-1}$ ) of neat liquid esters $\mathrm{R}^{1} \mathrm{COOCHXR}$.

\begin{tabular}{|c|c|c|c|c|c|}
\hline $\mathrm{X}, \mathrm{R}^{2}$ & $\mathrm{H}, \mathrm{C}_{6} \mathrm{H}_{5}$ & $\mathrm{Cl}, \mathrm{CH}_{3}$ & $\mathrm{Cl}, \mathrm{H}$ & $\mathrm{Cl}, \mathrm{C}_{6} \mathrm{H}_{5}$ & $\mathrm{Cl}, \mathrm{C}_{6} \mathrm{H}_{5} \mathrm{Cl}_{6}$ \\
\hline $\mathrm{R}^{1}$ & $1720^{a}$ & $1740^{a}$ & $1745^{a}$ & 1740 & - \\
$\mathrm{CH}_{3}$ & 1740 & $1760^{a}$ & $1765^{17}$ & 1770 & - \\
$\mathrm{CCl}_{3}$ & 1770 & - & $1780^{17}$ & 1785 & - \\
$\mathrm{CF}_{8}$ & 1790 & - & $1800^{a}$ & 1805 & 1820 \\
\hline
\end{tabular}

${ }^{a}$ Infrared spectrum taken by Dr. H. Laato in this laboratory.

Acknowledgements. The authors wish to thank Prof. Jaakko Paasivirta who took the NMR spectra and helped in their interpretation, Docent Heimo Laato for the sample of benzyl formate and some reference infrared spectra, and the National Research Council for Sciences (Valtion Luonnontieteellinen Toimikunta) for financial aid.

\section{REFERENCES}

1. Euranto, E. K., Noponen, A. and Kujanpää, T. Acta Chem. Scand. 20 (1966) 1273.

2. French, H. E. and Adams, R. J. Am. Chem. Soc. 43 (1921) 651.|

3. Ulich, L. H. and Adams, R. J. Am. Chem. Soc. 43 (1921) 660.

4. Staudinger, H. Ber. 42 (1909) 3966.

5. Staudinger, H. and Anthes, E. Ber. 46 (1913) 1426.

6. Adams, R. and Vollweiler, E. H. J. Am. Chem. Soc. 40 (1918) 1732.

7. Friedr. Bayer \& Co. Ger. Patent 121,223 (1900); Chem. Zentr. 72 II (1901) 69.

8. Arsi, M. Bull. Chem. Soc. Japan 37 (1964) 1280.

9. Laato, H. Suomen Kemistilehti B 38 (1965) 76.

10. Seubert, K. Ber. 21 (1888) 281.

11. Vogel, A. I. J. Chem. Soc. 19481833.

12. Bourne, E. J., Stacey, M., Tatlow, J. C. and Worrall, R. J. Chem. Soc. 19583268.

13. Pierce, A. C. and Joullié, M. M. J. Org. Chem. 27 (1962) 3968.

14. Thiele, J. and Dent, F. Ann. 302 (1898) 245.

15. Seelig, E. J. prakt. Chem. [2] 39 (1889) 157.

16. Euranto, E. and Kujanpää, T. Acta Chem. Scand. 15 (1961) 1209.

17. Laato, H. Ann. Univ. Turku., Ser. A I (1965) No. 82.

Received May 30, 1969. 